\title{
THE SUBSTANTIATION FOR INTRODUCTION OF THE INNOVATIVE TECHNOLOGICAL PROCESS FOR INDUSTRIAL PRODUCTION OF PARENTERAL DOSAGE FORMS BY THE EXAMPLE OF TORASEMIDE, SOLUTION FOR INJECTION
}

\author{
A.M.Goy \\ JSC «Farmak», Kyiv \\ Key words: parenteral dosage forms; Torasemide; solution for injection; innovative technological \\ process; algorithm; monitoring; critical parameters of the technological process; risk management \\ of pharmaceutical production \\ The introduction of the innovative technological process for industrial production of parenteral dosage \\ forms by the example of Torasemide, solution for injection has been substantiated in the article. The expe- \\ rimental studies for improving the manufacturing technology of Torasemide, solution for injection, $5 \mathrm{mg} / \mathrm{ml}$, \\ the choice of the filter material, the scientific substantiation of the innovative technological process \\ are presented. In particular, the aseptic conditions of production have been selected using sterile \\ filtration and thermal sterilization (stabilization), the algorithm of monitoring of the critical parameters \\ has been developed using the elements of risk management design of pharmaceutical production.
}

Creation of new effective parenteral dosage forms is a topical research and practical issue of pharmaceutical industry. In the context of this problem the innovative changes of pharmaceutical industrial production of sterile and aseptic dosage forms for injection require special attention. New active pharmaceutical ingredients, which differ in solubility and absorption affecting substantially bioavailability and therapeutic efficiency of a medicinal form, are not always stable in the process of thermal sterilization and further storage after sterilization. This leads to the necessity to improve the technology and introduce innovative approaches to sterile and aseptic production of parenteral dosage forms.

The history of studying and practical application of synthetic diuretics goes back more than 50 years, the last decades are marked with appearance of diuretics with new pharmacological properties [5].

Nowadays diuretics gain importance in treating congestive heart failure (CHF) and arterial hypertension in many countries, as well as in diseases of the liver and kidneys accompanied with edema. Diuretics are medications, which are more similar to those ones that can be suitable for the prolonged and continuous treatment of arterial hypertension. Diuretic drugs are used for reduction of edemas caused by water and salt retention in the body occurred in diseases of the heart, liver, kidneys and lungs. Mild diuretics are used in combination with other drugs in treating hypertension. Most diuretics often cause the electrolyte imbalance, washout of potas- sium salts from the body; therefore, simultaneously a patient is prescribed drugs, which contain potassium salts, in order to renew their deficiency in the body. Loop diuretics are the most potent; they block activity of special $\mathrm{Na}+/ 2 \mathrm{Cl}-/ \mathrm{K}+$ transporter in the tubular cells along the whole ascending segment of the Henle's loop. The diuretic action of these drugs is the strongest (the increase of diuresis in an adequate dose exceeds $100 \%$ of the original value) and remains even in the reduced renal function (the creatinine clearance is not below $5 \mathrm{ml} / \mathrm{min}$ ) $[1,5]$.

Secondary properties of loop diuretics are the ability to reduce moderately the carbonic anhydrase activity and stimulate the synthesis of renal vasodilator prostaglandins, first of all, prostaglandin E2 (PGE2). The increase of synthesis of PGE2 is accompanied by the additional increase of sodium reabsorption in the ascending part of the Henle's loop and decrease of free water reabsorption in collecting tubules. Thanks to such complex of effects loop diuretics are considered to be essential in the treatment of severe CHF.

The regular use of active diuretics provokes electrolyte disorders (the loss of potassium and magnesium), development of metabolic alkalosis. Besides, the constant use of loop drugs reduces their effect. It predetermines replacement of drugs of the same group [5].

Torasemide is the most effective modern loop diuretic. Bioavailability of Torasemide is twice as high as reference drug Furosemide (reaches $80-90 \%$ even in CHF). In comparative studies with Furosemide in 234 patients 
Torasemide lowered the risk of hospitalizations by $52 \%$ related to $\mathrm{CHF}$ exacerbation. Moreover, when examining 2303 patients with CHF who received Torasemide or Furosemide randomized in the ratio of $1: 1$ the reliable decrease of cardiovascular $(53 \%, \mathrm{p}<0.013)$ and general $(41 \%$, $\mathrm{p}=0.035)$ mortality was shown $[1,2]$.

The aim is to substantiate introduction of the innovative technological process for industrial production of parenteral dosage forms by the example of Torasemide, solution for injection.

\section{Materials and Methods}

Innovative implementations are difficult and expensive since development of an innovative molecule, a medicine, a dosage form has a number of difficulties. Some of them are: the targeted action focused on the physiological process, organ, system; the slower or increased action as a result of bioavailability; solubility and absorption; insufficient efficiency of the dosage form selected; a negative reactivity of the body, side effects; a degree of danger in use by patients with concomitant pathologies; in pediatric practice and gerontology; instability of parenteral solutions.

Difficulties related to industrial production are: economic costs for modernization of technological equipment and manufacturing processes, transfer of pharmaceutical technologies, and high competition.

The active pharmaceutical ingredient (AFI) - Torasemide is described in leading Pharmacopoeias (EP 6.0, USP 31, and British Ph. 2007). The scientific substantiation of the optimal composition of Torasemide, solution for injection, in the conditions of the technological laboratory of pharmaceutical production was performed using Torasemide substance produced by "Hubei Biocause Pharm. Co. Ltd." firm, China, and it fully complies with the requirements of EP 6.0.

Torasemide is a white or almost white powder, practically insoluble in water, slightly soluble in $96 \%$ alcohol, sparingly soluble in diluted solutions of alkali metal hydroxides and slightly soluble in diluted solutions of acids. From patented sources it is known that Torasemide exists in two forms: crystalline and amorphous. Torasemide shows polymorphism: there are four crystalline forms with different physical and chemical properties, in particular the melting point. To develop a medicine - Torasemide, solution for injection, $5 \mathrm{mg} / \mathrm{ml}$, a crystalline substance was used.

Thus, for improvement of the technological process it was necessary to transform of Torasemide API from the insoluble form into the soluble one. In turn, it led to introduction of such excipients into the dosage form as organic solubilizers, buffer system components for stabilization of the solution, $\mathrm{pH}$ adjustor, solvents to form the solution for injection (Tab. 1). In our study it has been found that the most stable solutions of Torasemide for injection are obtained by introducing, in addition to the organic solvent, physiologically compatible alkaline buffer solutions of sodium, potassium or ammonia salts, weak acids, such as carbonates, phosphates, glycinates or arginase, N-methylglucosamine or other amino acids. The qualitative composition of excipients required for
The qualitative composition of excipients required for improvement of the manufacturing technology of Torasemide, solution for injection

\begin{tabular}{|l|l|}
\hline \multicolumn{1}{|c|}{ Excipients } & \multicolumn{1}{c|}{ Functional purpose } \\
\hline Polyethyleneglycol 400 & $\begin{array}{l}\text { Organic solvent for preparation } \\
\text { of injectable dosage forms }\end{array}$ \\
\hline Trometamol & $\begin{array}{l}\text { Component of the buffer } \\
\text { system, stabilizer, pH adjustor }\end{array}$ \\
\hline Sodium hydroxide & $\begin{array}{l}\text { Component of the buffer } \\
\text { system, stabilizer, pH adjustor }\end{array}$ \\
\hline $\begin{array}{l}\text { 0.2 M sodium } \\
\text { hydroxide solution }\end{array}$ & $\begin{array}{l}\text { Component of the buffer } \\
\text { system, stabilizer, pH adjustor }\end{array}$ \\
\hline Water for injection & $\begin{array}{l}\text { Solvent for preparation of } \\
\text { injectable forms }\end{array}$ \\
\hline
\end{tabular}

Table 2

Physical and chemical properties of Torasemide, solution for injection, $5 \mathrm{mg} / \mathrm{ml}$, depending on the filter material

\begin{tabular}{|l|c|c|}
\hline \multicolumn{1}{|c|}{ Filter brand } & $\begin{array}{c}\mathrm{pH} \text { of the } \\
\text { solution }\end{array}$ & $\begin{array}{c}\text { Content of } \\
\text { Torasemide, } \\
\mathrm{mg} / \mathrm{ml}\end{array}$ \\
\hline Before filtration & 9.34 & 4.95 \\
\hline Polyethersulfone "Supor", Pall & 9.30 & 4.92 \\
\hline $\begin{array}{l}\text { Polyvinylidentetrafluoride } \\
\text { "VDF", Pall }\end{array}$ & 9.32 & 4.93 \\
\hline Neylon-66 "N-66", Pall & 9.12 & 4.65 \\
\hline
\end{tabular}

improvement of the manufacturing technology of Torasemide, solution for injection, is given in Tab. 1.

The substance of Torasemide for the model batch of Torasemide, solution for injection, $5 \mathrm{mg} / \mathrm{ml}$, is micronized with the micronization level of particles $-90 \%$ less than $5 \mu \mathrm{m}$. The drug substance and excipients are fully compatible with each other and do not form complexons that can adversely affect the efficacy of the drug.

To determine the mutual influence of the drug and filter materials that can cause a change of physical and chemical properties of the solution the filter materials widely used in production of solutions for injection were studied. The type of the filter material has also a considerable effect on indicators of "Sterility" and "Absence of Particulate Matters" tests. For this purpose, based on the optimal composition, the drug solution was prepared, filtered through various brands of membrane filters with particle size of $0.22 \mu \mathrm{m}$ and analyzed according to the basic physical and chemical parameters. The research results are presented in Tab. 2 .

According to the research data the filter material based on polyvinylidentetrafluoride and polyethersulfone was chosen for development of the technological process.

The selection of the thermal sterilization method was conducted in accordance with the requirements for sterilization of medicinal products developed by the Committee for Medicinal Products for Human Use in the Guideline CPMP/QWP/054/98 "Decision of trees for the selection of sterilization methods". 
Quality indicators of the model batch of Torasemide, solution for injection, $5 \mathrm{mg} / \mathrm{ml}$, and the reference drug Trifas 20

\begin{tabular}{|c|c|c|c|c|c|c|c|c|c|c|}
\hline \multirow[b]{3}{*}{ Model batch /Reference drug } & \multicolumn{5}{|c|}{ Before sterilization } & \multicolumn{5}{|c|}{ After thermal sterilization $\left(121^{\circ} \mathrm{C}, 15 \mathrm{~min}\right)$} \\
\hline & \multirow[b]{2}{*}{$\begin{array}{c}\text { Content, } \\
\mathrm{mg} / \mathrm{ml}\end{array}$} & \multicolumn{4}{|c|}{ Impurities } & \multirow[b]{2}{*}{$\begin{array}{c}\text { Content, } \\
\mathrm{mg} / \mathrm{ml}\end{array}$} & \multicolumn{4}{|c|}{ Impurities } \\
\hline & & $\begin{array}{l}\text { A: not } \\
\text { more } \\
\text { than } \\
0.1 \%\end{array}$ & $\begin{array}{l}\text { B: not } \\
\text { more } \\
\text { than } \\
1.2 \%\end{array}$ & $\begin{array}{l}\text { C, } \\
\%\end{array}$ & $\begin{array}{l}\text { D, } \\
\%\end{array}$ & & $\begin{array}{l}\text { A: not } \\
\text { more } \\
\text { than } \\
0.1 \%\end{array}$ & $\begin{array}{l}\text { B: not } \\
\text { more } \\
\text { than } \\
1.2 \%\end{array}$ & $\begin{array}{l}\text { C, } \\
\%\end{array}$ & $\begin{array}{l}\text { D, } \\
\%\end{array}$ \\
\hline $\begin{array}{l}\text { MC111207 } \\
\text { Torasemide, solution for } \\
\text { injection, } 5 \mathrm{mg} / \mathrm{ml} \text {, } \\
\text { (JSC "Farmak") }\end{array}$ & 5.02 & - & 0.05 & - & - & 4.70 & 0.10 & 4.67 & - & - \\
\hline $\begin{array}{l}61001 \\
\text { "Trifas 20" } \\
\text { (A. MENARINI MANUFACT. Italy) }\end{array}$ & 4.80 & - & 0.51 & - & - & 4.44 & 0.07 & 5.28 & - & - \\
\hline $\begin{array}{l}63004 \\
\text { "Trifas 20" } \\
\text { (A. MENARINI MANUFACT. Italy) }\end{array}$ & 4.78 & - & 0.70 & - & - & 4.48 & 0.06 & 5.57 & - & - \\
\hline $\begin{array}{l}71005 \\
\text { “Trifas 20” } \\
\text { (A. MENARINI MANUFACT. Italy) }\end{array}$ & 4.84 & - & 0.64 & - & - & 4.52 & 0.05 & 5.37 & - & - \\
\hline
\end{tabular}

Thus, to clarify the peculiarities of sterilization the model batch MC111207 Torasemide, solution for injection, $5 \mathrm{mg} / \mathrm{ml}$, in ampoules was sterilized at $121^{\circ} \mathrm{C}$ for 15 min (the pharmacopeial mode of thermal sterilization), and the changes of the main quality indicators (the quantitative content of Torasemide, impurities - decomposition products of Torasemide) were observed $[2,3,4]$.

For comparison ampoules of the reference drug Trifas 20 , solution for injection, manufactured by "A. MENARINI MANUFACTURING" company, Italy were also sterilized at $121^{\circ} \mathrm{C}$ for $15 \mathrm{~min}$. The results of the experiment are presented in Tab. 3 .

On the basis of the experimental results it can be concluded that improvement of the technological process by transformation of Torasemide in a soluble form, introduction of the solubilizer in the formulation and the buffer mixture for solution stabilization positively affect the drug stability, but the pharmacopeial mode of thermal sterilization causes the increase of impurities and exceeds their permissible content.

Thus, the necessity of introduction of innovative changes in the technological process was stated, namely the optimal method of thermal sterilization according to the requirements for sterilization of medicinal products in the Guideline CPMP/QWP/054/98 "Decision of trees for the selection of sterilization methods".

The next step of the drug development was the process of selection of the temperature conditions for thermal sterilization of the drug in ampoules. For this purpose the solution in ampoules was sterilized at the different modes of sterilization and, based on the results of the quantitative content of Torasemide and impurities in the drug (the drug model batch - MC111207 Torasemide, solution for injection, $5 \mathrm{mg} / \mathrm{ml}$, in ampoules) after sterilization the optimal mode of thermal sterilization was chosen. The results of the experiment are presented in Tab. 4.
Based on the results of the experimental study of the temperature conditions of thermal sterilization for model series batch MC111207 Torasemide, solution for injection, $5 \mathrm{mg} / \mathrm{ml}$, in ampoules, the optimal mode of thermal stabilization of aseptic drug manufacturing - sterile filtration and thermal sterilization (stabilization) has been determined; it fully provides the drug quality by the indicator for "Sterility" test.

Taking into account the overall results of the abovementioned experiments the innovative changes of the technological process for manufacturing Torasemide, solution for injection, $5 \mathrm{mg} / \mathrm{ml}$, have been scientifically substantiated. The aseptic conditions of production have been selected using sterile filtration and thermal sterilization (stabilization) at $105^{\circ} \mathrm{C}$ for $15 \mathrm{~min}$. The algorithm of monitoring of the critical parameters of the technological process for manufacturing Torasemide, solution for injection, $5 \mathrm{mg} / \mathrm{ml}$, has been developed.

The algorithm of monitoring of the critical parameters of the technological process for manufacturing Torasemide, solution for injection, $5 \mathrm{mg} / \mathrm{ml}$ :

When manufacturing Torasemide solution it is necessary to conduct bubbling of the solution with nitrogen within the whole period of loading and dissolution of Torasemide and before each sampling.

1. Critical parameter - the substance of Torasemide is easily oxidized, and it affects stability of the product; therefore, the whole technological process is conducted under the inert gas flow.

Water for injection is loaded with the temperature of $25^{\circ} \mathrm{C}$ into the reactor prepared. Polyethyleneglycol 400 and sodium hydroxide are added. They are mixed until the components become completely dissolved.

2. Critical parameter - duration of mixing is sufficient for dissolution of all components of the drug. 
Table 4

The results of the experimental study of temperature conditions of thermal sterilization in the model batch MC111207 Torasemide, solution for injection, $5 \mathrm{mg} / \mathrm{ml}$, in ampoules

\begin{tabular}{|c|c|c|c|c|c|}
\hline \multirow[b]{2}{*}{ No. of the drug batch } & \multirow{2}{*}{$\begin{array}{c}\text { The quantitative } \\
\text { content of Torasemide, } \\
\mathrm{mg} / \mathrm{ml}\end{array}$} & \multicolumn{4}{|c|}{ Impurities } \\
\hline & & $\begin{array}{l}\text { A: no more } \\
\text { than } 0.1 \%\end{array}$ & $\begin{array}{l}\text { B: no more } \\
\text { than } 1.2 \%\end{array}$ & $\mathrm{C}, \%$ & $D, \%$ \\
\hline \multirow{6}{*}{$\begin{array}{l}\text { Model batch } \\
\text { MC111207 } \\
\text { Torasemide, solution for } \\
\text { injection, } 5 \mathrm{mg} / \mathrm{ml}\end{array}$} & \multicolumn{5}{|c|}{ After thermal sterilization $\left(110^{\circ} \mathrm{C}, 20 \mathrm{~min}\right)$} \\
\hline & 4.78 & 0.08 & 1.9 & - & - \\
\hline & \multicolumn{5}{|c|}{ After thermal sterilization $\left(105^{\circ} \mathrm{C}, 30 \mathrm{~min}\right)$} \\
\hline & 5.01 & - & 1.3 & - & - \\
\hline & \multicolumn{5}{|c|}{ After thermal sterilization $\left(105^{\circ} \mathrm{C}, 15 \mathrm{~min}\right)$} \\
\hline & 5.01 & - & 0.77 & - & - \\
\hline
\end{tabular}

Torasemide is loaded and suspended by mixing for $30 \mathrm{~min}$ at increased speed of the mixer.

3. Critical parameter - the moisture content in the substance (the loss on drying, $\%$ ) - not more than $0.5 \%$.

4. Critical parameter-duration of mixing required for obtaining a homogeneous solution.

Stabilization of the solution ( $\mathrm{pH}$ 9.25-9.4).

5. Critical parameter $-\mathrm{pH}$ of the solution.

6. Critical parameter - duration of mixing.

In-process control of the intermediate product. In case of positive testing results the solution is filtered in a sterile tank.

7. Critical parameter - the filter membrane material that can cause the change of physical and chemical properties of the solution.

8. Critical parameter - leaktightness of filters, test for leaktightness before and after the filtration stage.

The solution filtered is poured into $2 \mathrm{ml}$ or $5 \mathrm{ml}$ ampoules made of transparent glass.

9. Critical parameter - the volume of the unit (ampoules) content checked during the manufacturing process.

10. Critical parameter - providing of hermetic sealing of ampoules.

11. Critical parameter - control of the drug solution for the absence of particulate matters.

Ampoules with the drug solution are sterilized (stabilized).
12. Critical parameter - temperature and duration of sterilization affecting physical and chemical properties of the drug.

\section{CONCLUSIONS}

1. In the process of the experimental research it has been found that the technological process must be improved by transformation of Torasemide API from the insoluble form into the soluble one. The selection and introduction of excipients have been carried out. They are: a solubilizer - Polyethyleneglycol 400; components of the buffer system, stabilizers, $\mathrm{pH}$ adjustors - Trometamol and $0.2 \mathrm{M}$ solution of sodium hydroxide, which positively affect the drug stability, are fully compatible with each other and do not form complexons that can adversely affect the efficacy of the drug.

2 . According to the research results the filter material based on polyvinylidentetrafluoride and polyethersulfone has been chosen.

3. The innovative technological process for manufacturing Torasemide, solution for injection, $5 \mathrm{mg} / \mathrm{ml}$, has been scientifically substantiated. In particular, the aseptic conditions of production have been selected using sterile filtration, the algorithm of monitoring of the critical parameters of the technological process for manufacturing Torasemide, solution for injection, $5 \mathrm{mg} / \mathrm{ml}$, has been developed.

\section{REFERENCES}

1. Achhammer J., Metz P. // Drugs. - 1991. - Vol. 41. - P. 80-91.

2. Engelhardt S., Meineke I., Brockmöller J. // J. of Chromatography B. - 2006. - Vol. 831, Issues 1-2. - P. 31-35.

3. European Pharmacopeia 7.5. General Notices apply to all monographs and other texts. - P. 4701-4702.

4. Jovic Z., Zivanovic L., Protic A. et al. // J. of Liquid Chromatography and Related Technol. - 2013. - Vol. 36, Issue 15. - P. 2082-2094.

5. Masereel B. // Eur. J. of Med. Chem. - 1995. - Vol. 30, №4. - P. 343-351. 


\section{ОБГРУНТУВАННЯ ВПРОВАДЖЕННЯ ІННОВАЦІЙНОГО ТЕХНОЛОГІЧНОГО ПРОЦЕСУ} ПРОМИСЛОВОГО ВИРОБНИЦТВА ПАРЕНТЕРАЛЬНИХ ЛІКАРСЬКИХ ФОРМ НА ПРИКЛАДІ ПРЕПАРАТУ ТОРАСЕМІД, РОЗЧИН ДЛЯ ІН'ЄКЦІЙ

\section{А.М.Гой}

Ключові слова: парентеральні лікарські фрорми; Торасемід; розчин для ін'єкцій; інноваційний технологічний процес; алгоритм; моніторинг; критичні параметри технологічного процесу; управління ризиками фрармацевтичного виробництва

Висвітлено обгрунтування впровадження інноваційного технологічного процесу промислового виробництва парентеральних лікарських форм на прикладі препарату Торасемід, розчин для ін'єкцій. Представлені експериментальні дослідження з удосконалення технології препарату Торасемід 5 мг/мл розчин для ін'єкцій, з вибору фрільтрувального матеріалу, наукового обірунтування інноваційного технологічного процесу, а саме: обрані асептичні умови виробництва із застосуванням стерильної фрільтрації і термічної стерилізації (стабілізації), алгоритм моніторингу критичних параметрів з використанням елементів проектування управління ризиками фрармацевтичного виробництва.

\section{ОБОСНОВАНИЕ ВНЕДРЕНИЯ ИННОВАЦИОННОГО ТЕХНОЛОГИЧЕСКОГО ПРОЦЕССА ПРОМЫШЛЕННОГО ПРОИЗВОДСТВА ПАРЕНТЕРАЛЬНЫХ ЛЕКАРСТВЕННЫХ ФОРМ НА ПРИМЕРЕ ПРЕПАРАТА ТОРАСЕМИД, РАСТВОР ДЛЯ ИНЪЕКЦИЙ \\ A.М.Гой}

Ключевые слова: парентеральные лекарственные фрормы; Торасемид; раствор для инъекций; инновационный технологический процесс; алгоритм; мониторинг; критические параметры технологического процесса; управление рисками фрармацевтического производства

Обосновано внедрение инновационного технологического процесса промышленного производства парентеральных лекарственных форм на примере препарата Торасемид, раствор для инъекций. Представлены экспериментальные исследования усовершенствования технологии получения препарата Торасемид 5 мг/мл раствор для инъекций, технологии выбора фрильтровального материала, научного обоснования инновационного технологического процесса, а именно: выбраны асептические условия производства с применением стерильной фрильтрации и термической стерилизации (стабилизации), алгоритм мониторинга критических параметров с использованием элементов проектирования управления рисками фрармацевтического производства. 